\title{
Interchromosomal, intercellular and interindividual variability of NORs studied with silver staining and in situ hybridization
}

\author{
FEDERICO ZURITA, ANTONIO SÁNCHEZ†, MIGUEL BURGOS, RAFAEL JIMÉNEZ \& \\ RAFAEL DIAZ DE LA GUARDIA* \\ Departamento de Genética, Facultad de Ciencias, Universidad de Granada, Fuentenueva S/N, 18071 Granada, Spain
}

\begin{abstract}
We investigated the relationship between transcriptional activity and the quantity of ribosomal cistrons of the nucleolar organizing regions (NORs) in chromosomal pair 3 of the Spanish mole Talpa occidentalis. Transcriptional activity was estimated by the size of conventional silver-staining signals. The number of ribosomal cistrons was estimated by the size of the in situ hybridization signals obtained with a ribosomal DNA probe. A sample of cells was studied with each method in four different individuals, and the results obtained with the two techniques were compared. Furthermore, sequential analysis on the same cells was carried out to study the association of interstitial nucleolar constrictions with silver staining and in situ hybridization. Interchromosomal, intercellular and interindividual variability were found with both silver staining and in situ hybridization methods. Our results show that transcriptional activity of NORs does not depend exclusively on the number of ribosomal cistrons they have as a high percentage of cells had two NORs with abundant ribosomal cistrons, only one of which was active. Additional factors, probably responsible for the activation of transcription, may be involved in this variability.
\end{abstract}

Keywords: Ag staining, in situ hybridization, NOR, nucleolar organizing regions, ribosomal cistrons.

\section{Introduction}

Silver staining (Ag staining) is the cytogenetic method most commonly used to detect the position of nucleolar organizing regions (NORs) on chromosome preparations (Goodpasture \& Bloom, 1975). However, the biological significance of this technique remains unclear, and has been the cause of much debate for several years.

An association between Ag staining and transcriptional activity of ribosomal genes during the preceding interphase was suggested by several authors (Howell, 1977; Hubbell, 1985). This hypothesis has been refuted by others (Raman \& Sperling, 1981; Medina et al., 1983), who supported the view that Ag staining requires only a decondensed state of the NOR chromatin (nucleolar constriction) to occur.

\footnotetext{
*Correspondence. E-mail: mburgos@goliat.ugr.es

†Current address: Departamento de Biología Experimental y Ciencias de la Salud, Facultad de Ciencias Experimentales, Universidad de Jaén, Paraje las Lagunillas S/N, 23071 Jaén, Spain.
}

Jiménez et al. (1988) demonstrated that decondensation of NORs is neccesary but not sufficient for $\mathrm{Ag}$ staining, and suggested that preceding transcriptional activity is also needed.

Furthermore, considerable intercellular and interindividual variability in both the size and number of Ag-stained NORs (Ag-NORs) has been reported in most species analysed up to now (Schmid, 1982; Sánchez et al., 1989, 1990; Suzuki et al., 1990). This variability may be a consequence of differences in the rRNA requirements of cells in the preceding interphase (Sánchez et al., 1989).

In situ hybridization (ISH) with rDNA probes has also been used to study NORs. Although this is a qualitative rather than a quantitative technique, an association between the size of the hybridization signal observed in a given NOR and the number of ribosomal cistrons it contains has been proposed (Wachtler et al., 1986; Suzuki et al., 1990; Leitch \& Heslop-Harrison, 1992). Similarly, the size of the ISH signal was also proposed to be associated with the size of the $\mathrm{Ag}$ staining signal (Schubert \& Künzel, 1990). According to these hypotheses, a 
relationship between the number of ribosomal cistrons (as evidenced by in situ hybridization) and NOR size (as evidenced by $\mathrm{Ag}$ staining) could indeed exist, although direct evidence is still lacking.

In anurans the length of the nucleolar constrictions is associated with the size of the corresponding $\mathrm{Ag}$ staining signals (Schmid, 1982). Similarly, associations between the presence or absence of secondary constrictions and the presence or absence of $\mathrm{Ag}$ signals at NOR positions were found in the insectivorous mole Talpa occidentalis and in the rodent Eliomys quercinus (Jiménez et al., 1988). The former mammalian species is especially useful for the study of NORs because: (i) moles have a single pair of NOR-carrying chromosomes; (ii) the NORs are located interstitially, so that their condensation status is easy to observe; and (iii) interindividual and intercellular variability in $\mathrm{Ag}$ staining of NORs have been found.

In this article we analyse the relationships between the number and size of (i) nucleolar secondary constrictions, (ii) Ag signals, and (iii) ISH signals, on the basis of data obtained by counting cell populations and from the sequential observation of ISH material destained with DePex.

\section{Materials and methods}

A total of four individuals (two males and two females) of the mole species Talpa occidentalis (Insectivora, Mammalia) were trapped live in Vega de Granada (Granada province, southern Spain) by using home-made mole traps (unpublished data). Chromosome preparations were made from bone marrow cells in accordance with our standard air-drying procedure (Burgos et al., 1986). Ag stain- ing was carried out according to the method of Rufas et al. (1982).

For in situ hybridization to fixed metaphase chromosomes we used a Syrian hamster rDNA probe consisting of sequences corresponding to the $3^{\prime}$ end of the $18 \mathrm{~S}$ gene, the internal transcribed spacer and almost the entire $28 \mathrm{~S}$ gene (see Wahl et al., 1983). Nick translation labelling with digoxygenin and hybridization were carried out in accordance with the protocol recommended by the supplier (Boehringer Mannheim). Chromosome preparations were counterstained for $1 \mathrm{~min}$ with 5 per cent Giemsa.

For sequential analysis, in situ hybridized metaphase plates were photographed in preparations mounted in a 1:1 mixture of glycerol and distilled water. Then preparations were mounted in DePex, and when hybridization signals had completely disappeared, the same plates were photographed again for secondary constriction studies, as they retained the Giemsa counterstaining.

Results were statistically tested by using the Contingence Tables procedure included in the STATGRAPHICS PC software package.

\section{Results}

According to cytogenetic data previously reported for the species Talpa occidentalis (Jiménez et al., 1984), the mole individuals analysed in this study showed a karyotype of $2 n=34$ chromosomes, and a single NOR was located interstitially at the large secondary constriction in chromosome pair 3 .

Initially we scored a total of 639 in situ hybridized metaphase plates. On the basis of the size and inten-

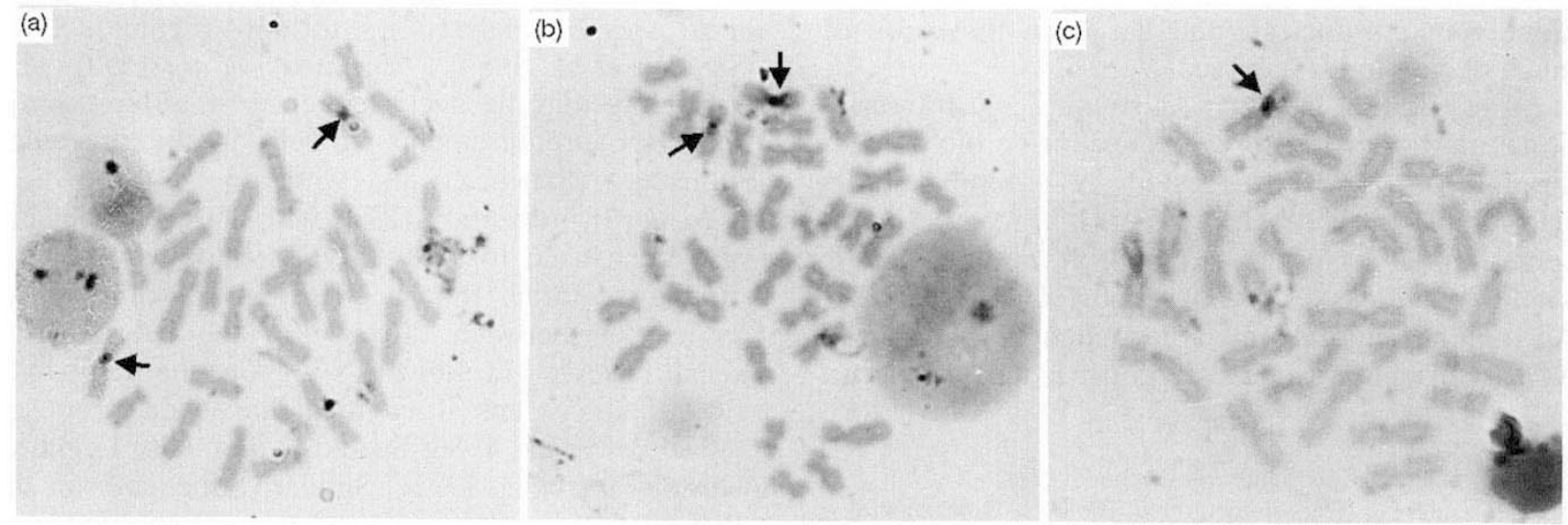

Fig. 1 Variation in the number and size of the ISH-NORs in Talpa occidentalis. Metaphase plates were found to have two ISH signals of similar size (a), two ISH signals of different size (b), and a single ISH signal (c). 
sity of the hybridization signal, three cell types could be distinguished: (i) cells with two signals of similar size and intensity; (ii) cells with two different signals; and (iii) cells with a single signal (Fig. 1). Table 1 summarizes the number of these cell types in each particular individual. Interindividual differences were evident $\left(\chi_{6}^{2}=62.47 ; P=0.0000\right)$.

In a second experiment, a total of $579 \mathrm{Ag}$ stained metaphase plates were scored. Similarly, three cell types could be recognized: (i) cells with two identical signals; (ii) cells with two different signals; and (iii) cells with a single signal (Fig. 2). Table 2 summarizes the distribution corresponding to these cells. Interindividual differences were also clear in this case $\left(\chi_{6}^{2}=44.02 ; P=0.0000\right)$.

Furthermore, a sequential analysis of both homologous chromosomes in a total of 80 cells was carried out to determine the size of the ISH signal and the nucleolar constriction (Fig. 3). In each cell we compared the size of the nucleolar constriction with

Table 1 Distribution of three different cell types in four Talpa occidentalis individuals, according to the number and intensity of ISH signals

\begin{tabular}{lccc}
\hline & \multicolumn{3}{c}{ Numbers of cells with } \\
\cline { 2 - 4 } Individual & $\begin{array}{c}\text { Single } \\
\text { ISH signal }\end{array}$ & $\begin{array}{c}\text { Two identical } \\
\text { ISH signals }\end{array}$ & $\begin{array}{c}\text { Two different } \\
\text { ISH signals }\end{array}$ \\
\hline T-420 & 2 & 121 & 92 \\
T-421 & 2 & 67 & 66 \\
T-422 & 7 & 44 & 29 \\
T-423 & 1 & 166 & 42 \\
Mean $\%$ & 2.6 & 60.1 & 37.3 \\
\hline
\end{tabular}

the size of the ISH signal in each chromosome with respect to its homologue. In 64 per cent of the cells, the chromosome with the largest ISH signal also had the largest nucleolar constriction. In the remaining cells (36 per cent) the opposite situation was seen, i.e. the chromosome with the largest ISH signal showed the shortest nucleolar constriction.

Finally, the results obtained with both ISH and Ag-NOR techniques in each particular individual were tested in contingency tables with respect to the three cell types observed. Table 3 summarizes the $\chi^{2}$ values and the significance levels of these tests. The existence of significant differences clearly demonstrates that the distribution of cell types depends on the technique used.

\section{Discussion}

Workers using the $\mathrm{Ag}$ staining technique have described NOR polymorphism and heteromorphism

Table 2 Distribution of three different cell types in four Talpa occidentalis individuals, according to the number and intensity of $\mathrm{Ag}$ signals

\begin{tabular}{lccc}
\hline & \multicolumn{3}{c}{ Numbers of cells with } \\
\cline { 2 - 4 } Individual & $\begin{array}{c}\text { Single } \\
\text { Ag signal }\end{array}$ & $\begin{array}{c}\text { Two identical } \\
\text { Ag signals }\end{array}$ & $\begin{array}{c}\text { Two different } \\
\text { Ag signals }\end{array}$ \\
\hline T-420 & 57 & 22 & 26 \\
T-421 & 197 & 35 & 89 \\
T-422 & 24 & 21 & 26 \\
T-423 & 37 & 30 & 15 \\
Mean \% & 48.6 & 24.5 & 26.9 \\
\hline
\end{tabular}
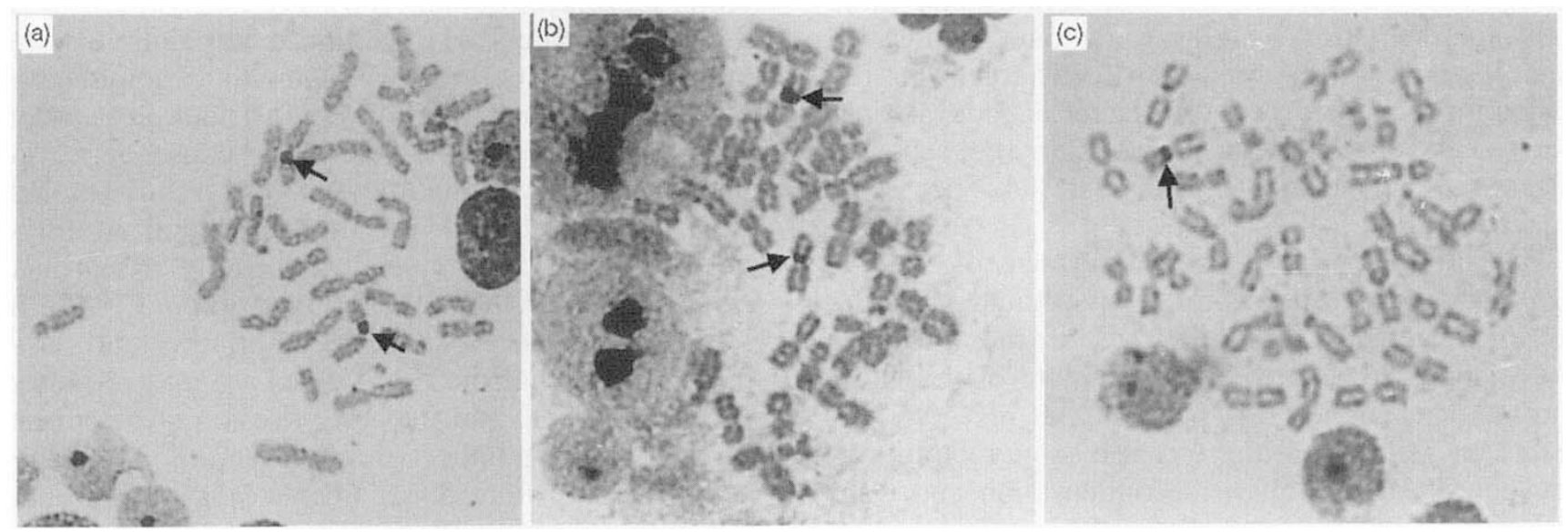

Fig. 2. Variation in the number and size of the Ag-NORs in Talpa occidentalis. Metaphase plates were found to have two $\mathrm{Ag}$ signals of similar size (a), two Ag signals of different size (b) and one Ag signal (c). 

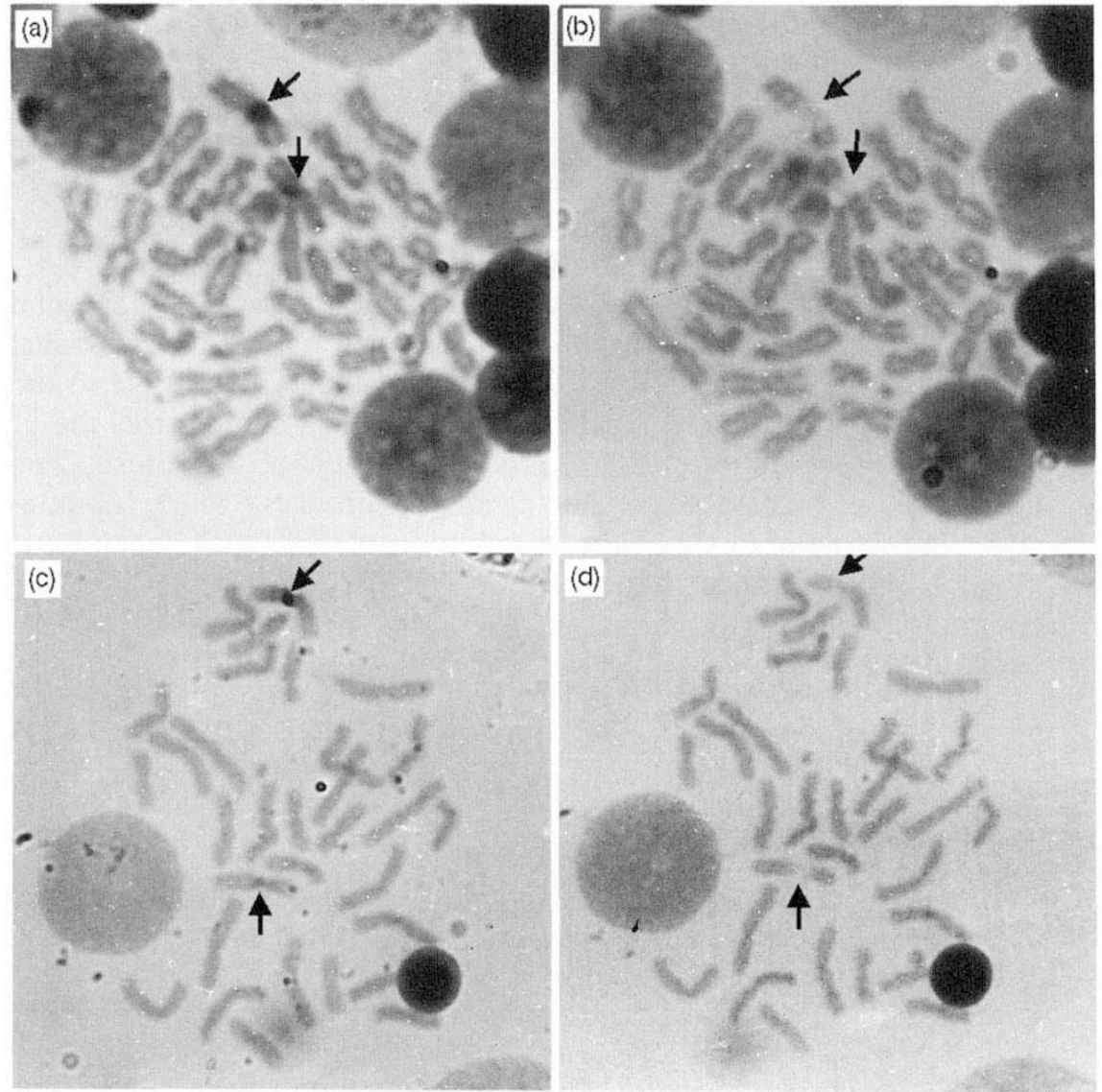

Fig. 3. Sequential analysis of the size of both ISH signal and nucleolar constriction in the same cells of Talpa occidentalis. ( $\mathrm{a}$ and $\mathrm{b}$ ) Metaphase plate showing two ISH signals of different size where the chromosome with the larger ISH signal also presented the larger nucleolar constriction. (c and d) Metaphase plate showing the opposite situation. in amphibians (Schmid, 1982), fishes (Gold, 1984) and mammals, including humans (Mayr et al., 1984; Sasaki et al., 1986; Sánchez et al., 1989, 1990; Suzuki et al., 1990; Mellink et al., 1994). In view of the association between the size of the $\mathrm{Ag}$ signal and transcriptional activity of the NOR (Miller et al, 1976), such a heteromorphism is probably a consequence of transcriptional differences between NORs. Accordingly, in 48.5 per cent of the mole cells analysed in this study, only one of the two homologous NORs was active, whereas in the remaining 51.4 per cent of the cells, both NORs were active irrespective of whether they showed different (26.9 per cent) or similar (24.5 per cent) Ag signals.

The presence (or absence) and size of the $\mathrm{Ag}$ signal were also shown to be associated with the presence (or absence) and size of the nucleolar constriction, i.e. the decondensed state of the NOR chromatin (Schmid, 1982; Jiménez et al., 1988). It seems, therefore, that there is also some relationship between NOR chromatin decondensation and transcriptional activity.

When the ISH technique is used to study NORs, the presence and the size of the ISH signal depends on the number of ribosomal cistrons in each particular NOR (Appels et al., 1980; Wachtler et al., 1986; Suzuki et al., 1990; Leitch \& Heslop-Harrison, 1992). Our results indicate that 60.1 per cent of mole cells had a similar number of ribosomal cistrons in both homologous chromosomes, 37.3 per cent had a different number, and in 2.6 per cent of the cells one of the NOR-carrying chromosomes either lacked ribosomal cistrons or had too few to be detected by the ISH technique. Variability in the number of ribosomal cistrons in homologous chromosomes and their uneven distribution between cells have been explained as a consequence of unequal interchromatidic or interchromosomal exchanges which give rise to either duplications or deletions of a variable portion of the NOR chromatin (Shubert \& Wobus, 1985; Gillings et al., 1987). In this respect, the existence of interindividual variability implies that these processes are also produced in the germ line, and thus give rise to polymorphism for the mean number of NOR chromosomes per cell. Mole individual T-422 (Table 1 ) is a representative example of this phenomenon.

The variability we found with both $\mathrm{Ag}$ staining and ISH techniques in the same material raises the 
Table 3 Contingency tables corresponding to four different individuals of Talpa occidentalis with $\chi^{2}$ and significance level values, calculated to test the possible association between the staining technique used (ISH or Ag-NOR) and the resulting cell types

\begin{tabular}{|c|c|c|c|c|c|c|}
\hline \multirow[b]{2}{*}{ Individual } & \multirow[b]{2}{*}{ Technique } & \multicolumn{3}{|c|}{ Numbers of cells with } & \multirow[b]{2}{*}{$\chi_{2}^{2}$} & \multirow[b]{2}{*}{$P$} \\
\hline & & $\begin{array}{l}\text { One single } \\
\text { signal }\end{array}$ & $\begin{array}{l}\text { Two identical } \\
\text { signals }\end{array}$ & $\begin{array}{l}\text { Two different } \\
\text { signals }\end{array}$ & & \\
\hline $\mathrm{T}-420$ & $\begin{array}{l}\text { ISH } \\
\text { Ag-NOR }\end{array}$ & $\begin{array}{r}2 \\
57\end{array}$ & $\begin{array}{r}121 \\
22\end{array}$ & $\begin{array}{l}92 \\
26\end{array}$ & 134.85 & $<0.0001$ \\
\hline $\mathrm{T}-421$ & $\begin{array}{l}\text { ISH } \\
\text { Ag-NOR }\end{array}$ & $\begin{array}{r}2 \\
197\end{array}$ & $\begin{array}{l}67 \\
35\end{array}$ & $\begin{array}{l}66 \\
89\end{array}$ & 154.34 & $<0.0001$ \\
\hline $\mathrm{T}-422$ & $\begin{array}{l}\text { ISH } \\
\mathrm{Ag}-\mathrm{NOR}\end{array}$ & $\begin{array}{r}7 \\
24\end{array}$ & $\begin{array}{l}44 \\
21\end{array}$ & $\begin{array}{l}29 \\
26\end{array}$ & 17.15 & 0.0002 \\
\hline $\mathrm{T}-423$ & $\begin{array}{l}\text { ISH } \\
\text { Ag-NOR }\end{array}$ & $\begin{array}{r}1 \\
37\end{array}$ & $\begin{array}{r}166 \\
30\end{array}$ & $\begin{array}{l}42 \\
15\end{array}$ & 106.03 & $<0.0001$ \\
\hline
\end{tabular}

question as to whether interchromosomal transcriptional differences result exclusively from differences in the number of ribosomal cistrons. Because technical reasons preclude for the moment the sequential observation of both $\mathrm{Ag}$ and ISH signals in the same chromosome, further indirect evidence is needed to demonstrate such a relationship. Comparison between data obtained in both ISH and Ag-NOR experiments (Tables 1 and 2) suggests that a high number of NOR-carrying chromosomes were transcriptionally inactive, as they lacked the $\mathrm{Ag}$ signal, despite the fact that they possessed enough ribosomal cistrons to be detected by the ISH technique. Significant $\chi^{2}$ values shown in Table 3 clearly demonstrate this hypothesis. Hence chromosomes with similar numbers of ribosomal cistrons (similar ISH signals) may show different transcriptional activities (different $\mathrm{Ag}$ signals). Similar data were reported in different subspecies and strains of the mouse Mus musculus (Suzuki et al., 1990, 1992). We conclude that the level of transcriptional activity does not depend exclusively on the number of ribosomal cistrons, and that additional factors responsible for the activation of transcription are also involved, and contribute to the variability in NOR activity. Further indirect evidence was obtained by comparing data from the sequential analysis of the nucleolar constriction and both $\mathrm{Ag}$ and ISH signals in separate cell samples. A direct association between the size of the nucleolar constriction and the Ag signal has been reported (Schmid, 1982; Jiménez et al., 1988). However, no such association between the size of the nucleolar constriction and the ISH signal was observed in this study. These findings support our hypothesis because if transcriptional activity (size of the $\mathrm{Ag}$ signal) depended exclusively on the number of ribosomal cistrons (size of the ISH signal), these two variables would be associated with the size of the nucleolar constriction. Factors responsible for transcription activation probably also influence the size of the nucleolar constriction.

\section{Acknowledgements}

This work was supported by the Spanish DGICYT through project No PB92-0951, and by the Junta de Andalucía through Group No. 1278. We thank Ms Karen Shashok for revising the English style of the manuscript.

\section{References}

APPEl.S, R., GERLACHI, w. L., DENNIS, E. S., SWIFT, H. AND PEACOCK, w. J. 1980. Molecular and chromosomal organization of DNA sequences coding for the ribosomal RNAs in cereals. Chromosoma, 78, 293-311.

BURGOS, M., JIMÉNEZ, R. AND DÍAZ DE LA GUARDIA, R. 1986. A rapid, simple and reliable combined method for G-banding mammalian and human chromosomes. Stain Technol., 61, 257-260.

GILLINGS, M. R., FRANKHAM, R., SPEIRS, J. AND WHALLEY, M. 1987. $X-Y$ exchange and the coevolution of the $X$ and $Y$ rDNA arrays in Drosophila melanogaster. Genetics, 116, 241-251.

GOLD, J. R. 1984. Silver staining and heteromorphism of chromosomal nucleolus organizer regions in North American cyprinid fishes. Copeia, 1, 33-139. 
GOODPASTURE, C. AND BLOOM, S. E. 1975. Visualization of nucleolar organizer regions in mammalian chromosomes using silver staining. Chromosoma, 53, 37-50.

HOWELL, w. M. 1977. Visualization of ribosomal gene activity: silver stains proteins associated with rRNA transcribed from oocyte chromosomes. Chromosoma, 62, 361-367.

HUBBELL, H. R. 1985. Silver staining as an indicator of active ribosomal genes. Stain Technol., 60, 285-294.

JIMÉNEZ, R., BURGOS, M. AND DÍAZ DE LA GUARDIA, R. 1984. Karotype and chromosome banding in the mole (Talpa occidentalis) from the South-East of the Iberian Peninsula. Implication on its taxonomic position. Caryologia, 37, 253-258.

JIMÉNEZ, R., BURGOS, M. AND DÍAZ DE LA GUARDIA, R. 1988. A study of the Ag-staining significance in mitotic NOR's. Heredity, 60, 125-127.

LEITCH, 1. J. AND HESLOP-HARRISON, J. S. 1992. Physical mapping of the $18 \mathrm{~S}-5.8 \mathrm{~S}-26 \mathrm{~S}$ rRNA genes in barley by in situ hybridization. Genome, 35, 1013-1018.

MAYR, B., SCHWEIZER, D. AND GEBER, G. 1984. NOR activity, heterochromatin differentiation and the Robertsonian polymorphism in Sus scrofa L. J. Hered, 75, 79-80.

MEDINA, F. J., RISUEÑO, M. C., SÁNCHEZ-PINA, M. A. AND FERNÁNDEZ-GÓMEZ, M. E. 1983. A study on nucleolar silver staining in plant cells. The role of argyrophilic proteins in nucleolar physiology. Chromosoma, 88, 149-155.

MELLINK, C. H. M., BOSMA, A. A. AND DE HAAN, N. A. 1994. Variation in size of Ag-NORs and fluorescent rDNA in situ hybridization signals in six breeds of domestic pig. Hereditas, 120, 141-149.

MILLER, D. A., DEV, V. G., TANTRAVAHI, R. AND MILLER, O. J. 1976. Suppression of human nucleolus organizer activity in mouse-human somatic hybrid cells. Exp. Cell Res., 101, 235-243.

RAMAN, R. AND SPERling, K. 1981. Patterns of silver staining on NORs of prematurely condensed muntjac chromosomes following RNA inhibition. Exp. Cell Res, $135,373-378$.
RUFAS, J. S., ITURRA, P., DE SOUZA, W. AND ESPONDA, P. 1982. Simple silver staining procedure for the lozalization of nucleolus and nucleolar organizers under light and electron microscopy. Arch. Biol., 93, 267-276.

SÁNCHEZ, A., BURGOS, M., JIMÉNEZ, R. AND DÍAZ DE LA GUARDIA, R. 1989. Quantitative analysis of silver staining on the nucleolar organizing regions in Eliomys quercinus. Genome, 32, 978-982.

SÁNCHEZ, A., BURGOS, M., JIMÉNEZ, R. AND DíAZ DE LA GUARDIA, R. 1990. Variable conservation of nucleolus organizer regions during karyotypic evolution in Microtidae. Genome, 33, 119-122.

SASAKI, M., NISHIDA, C. AND KODAMA, Y. 1986. Characterization of silver stained nucleolus organizer regions (Ag-NORs) in 16 inbred strains of the Norway rat, Rattus norvegicus. Cytogenet. Cell Genet., 41, 83-88.

sCHMiD, M. 1982. Chromosome banding in Amphibia. VII. Analysis of the structure and variability of NORs in Anura. Chromosoma, 87, 327-344.

SCHUBERT, I. AND KÜNZEL, G. 1990. Position-dependent NOR activity in barley. Chromosoma, 99, 352-359.

SCHUBERT, I. AND wOBUS, U. 1985. In situ hybridization confirms jumping nucleolus organizing regions in Allium. Chromosoma, 92, 143-148.

SUZUKI, H., KURIHARA, Y., KANEHISA, T. AND MORIWAKI, K. 1990. Variation in the distribution of silver-stained nucleolar organizing regions on the chromosomes of the wild mouse Mus musculus. Mol. Biol. Evol., 7, 271-282.

SUZUKI, H., SAKURAI, S., NISHIMURA, M., KOMINAMI, R. AND MORIWAKI, K. 1992. Compensatory changes in silverstainability of nucleolar organizer regions in mice. Jap. J. Genet., 67, 217-232.

WACHTLER, F., HOPMAN, A. H., WIEGANT, J. AND SCHWARZACHER, H. G. 1986. On the position of nucleolus organizer regions (NORs) in interphase nuclei. Studies with a new, non-autoradiographic in situ hybridization method. Exp. Cell Res., 167, 227-240.

WAHL, G. M., VITTO, L. AND RUBNITZ, J. 1983. Co-amplification of rRNA genes with CAD genes in $\mathrm{N}$-(phosphonoacetyl)-L-aspartate-resistant Syrian hamster cells. Mol. Cell Biol., 3, 2066-2075. 